\title{
Biomedical Sciences Perspectives
}

\author{
KS Yadav* \\ Associate Professor in Medical Biochemistry, India
}

Submission: February 17, 2017; Published: March 17, 2017

"Corresponding author: KS Yadav, Associate Professor in Medical Biochemistry, Member Secretary, of IEC, School of Medicine, D Y Patil University, Navi Mumbai 400706, India, Email: ks.yadav@dypatil.edu

\section{Editorial}

Biomedical Engineering (BME) is one of the youngest disciplines in engineering and has made tremendous progress in the last few decades. Bioinstrumentation is the application of electronics and measurement techniques to develop devices used in diagnosis and treatment of disease.

This has been aided by rapid advancements in Semiconductor Technology, Information Technology, and Biotechnology. In the field of Biomedical Engineering, researchers with expertise in diverse areas work towards the unified goal of creating products and techniques for better health care. The BME is a heterogeneous class researchers and academicians those promotes involvement of intellectuals and executors provides opportunities for research in exciting interdisciplinary areas.

Integration of various domains is being conducted in some areas, but due to limited resources and expertise most of the applied segments are underutilized and least focused in undeveloped or underdeveloped countries. Even in some developed countries use of biomedical transducers, biosensors, biomaterials tissue engineering,bionanotechnology,biophysics, cellular mechanics and computational biology is limited. There are many applications of BME in health sector like controlled drug delivery,computational neurophysiology, microfabrication and microfluidics, telemedicine and medical information system. Following listed key areas of tomorrow's requirements of health sectors and we all professional must think seriously;

a. Conservation of biomaterial of living tissue and development in artificial tissue industry. To boost these sector. Knowledge oftissue dynamic and behavior of living material is of prime importance in the design of implant materials. b. To understand biomechanical tissue engineering of live tissue or artificial tissue knowledge of statics, dynamics, fluids, solids, thermodynamics, and continuum mechanics is essential.

c. Main hurdle in developments in this area is lacking of integration between applied scientist and technologists. So development in the field of biomechanics is open solution to classical mechanics (statics, dynamics, fluids, solids, thermodynamics, and continuum mechanics) to biological or medical problems.

d. At some extent development in genetic engineering technologist attempts to attack biomedical problems at the microscopic level. These areas utilize the anatomy, biochemistry, and mechanics of cellular and subcellular structures in order to understand disease processes and to be able to intervene at very specific sites.

e. Further development of clinical engineering in terms of robotics, preservation and storage of clinical database, high speed images transfer with quality resolution, computational mechanics, orthopedic bioengineering, development artificial biomaterials and its integration with BME enhances quality of health sector delivery.

f. Rehabilitation of diseased is area of gray concern. Development in this sector may enhance the capabilities and quality of life for individuals with physical and cognitive impairments.

If you want to be incrementally better: Be competitive. If you want to be exponentially better: Be cooperative. 
This work is licensed under Creative Commons Attribution 4.0 License DOI: 10.19080/CTBEB.2017.02.555584
Your next submission with Juniper Publishers will reach you the below assets

- Quality Editorial service

- Swift Peer Review

- Reprints availability

- E-prints Service

- Manuscript Podcast for convenient understanding

- Global attainment for your research

- Manuscript accessibility in different formats

( Pdf, E-pub, Full Text, Audio)

- Unceasing customer service

Track the below URL for one-step submission https://juniperpublishers.com/online-submission.php 